\title{
Serum lipids of pemphigus foliaceus patients on long-term glucocorticoid therapy
}

\author{
Lípides séricos de pacientes com pênfigo foliáceo sob \\ tratamento prolongado com corticóides
}

\begin{abstract}
Selma Freire de Carvalho da Cunha1 ${ }^{23}$, Vitorino Modesto dos Santos ${ }^{13}$, Jacqueline Pontes Monteiro ${ }^{23}$, Tácio Pierre Sousa Ferreira ${ }^{2}$, Jenner Arruda Modesto dos Santos ${ }^{1}$, Taciana Arruda Modesto dos Santos ${ }^{1}$ and Daniel Ferreira da Cunha ${ }^{123}$
\end{abstract}

\begin{abstract}
Endemic pemphigus foliaceus, and long-term corticotherapy may affect serum lipid levels. The aim of this study was to compare serum lipids of pemphigus foliaceus patients on glucocorticoid therapy to a healthy control group. Fifteen patients receiving prednisone $(0.33 \pm 0.22 \mathrm{mg} / \mathrm{kg})$ for at least 12 months and 15 controls were submitted to 48- $h$ food intake records, anthropometry, and biochemical measurements. Data were compared by $\chi^{2}$, Mann-Whitney and Student " $t$ " tests. The groups were matched for gender, age, weight, body mass index, arm circumference and triceps skin fold. No differences were observed in relation to energy, fat, protein and carbohydrate daily intakes, total cholesterol, HDL, LDL, uric acid, and serum creatinine levels. Pemphigus foliaceus patients had higher triglyceride [159 (64-371) vs. 100 (45-133) mg/dl], VLDL [32 (13-74) vs. 20 (9114) $\mathrm{mg} / \mathrm{dl}]$ and ESR [44 (9-87) vs. 7 (1-30) $\mathrm{mm} / \mathrm{h}$ ] levels than controls, probably due to metabolic effects of inflammatory disease and corticotherapy.
\end{abstract}

Key-words: Pemphigus foliaceus. Glucocorticoid therapy. Serum lipids. Triglycerides.

Resumo Pênfigo foliáceo endêmico e corticoterapia prolongada podem afetar a lipidemia. O objetivo foi comparar os níveis de lípides séricos de pacientes com pênfigo cronicamente tratados com glicocorticóides e controles normais. Quinze pacientes recebendo prednisona $(0,33 \pm 0,22 \mathrm{mg} / \mathrm{kg})$ pelo menos por 12 meses e 15 indivíduos normais foram submetidos a registro da ingestão alimentar de 48horas, antropometria e dosagens bioquímicas. Os dados foram comparados pelos testes do $\chi^{2}$, Mann-Whitney e " $t$ " de Student. Os grupos estavam pareados para sexo, idade, peso, índice de massa corporal, circunferência do braço e prega tricipital. Não houve diferença na ingestão diária de energia, lipídios, proteína e carboidratos ou níveis séricos de HDL, LDL, colesterol, creatinina e ácido úrico. Pacientes apresentaram níveis mais elevados de triglicerídeos [159 (64-371) vs. 100 (45-133) mg/dl], VLDL [32 (13-74) vs. 20 (9-114) mg/dl] e VHS [44 (9-87) vs. 7 (1-30)mm/h] que controles, provavelmente devido a efeitos metabólicos da inflamação mais corticoterapia.

Palavras-chaves: Pênfigo foliáceo. Tratamento com corticóides. Lípides séricos. Triglicérides.

Endemic pemphigus foliaceus is a chronic inflammatory blistering disease in which acantholysis occurs in the upper portion of the prickle layer of epidermis ${ }^{710}$. Generalized pemphigus foliaceus is often associated with metabolic changes ${ }^{2}$, including muscle hypercatabolism and increased resting energy expenditure, in addition to increased glucose blood levels and peripheral insulin resistance. During sepsis and severe inflammation, elevated plasma lipid levels may also occur ${ }^{1}$, due to the increased synthesis and secretion of triglyceride-rich lipoproteins by the liver, and the inhibition of lipoprotein lipase ${ }^{12}$.

Long-term systemic glucocorticoids administration has been utilized to control clinical manifestations of generalized pemphigus ${ }^{5}$ and, besides increasing appetite

\footnotetext{
1. Department of Internal Medicine. 2. Discipline of Nutrology. 3. Pathology Post-graduation Course of Faculdade de Medicina do Triângulo Mineiro, Uberaba, Minas Gerais State, Brazil.

Address to: Dr. Daniel Ferreira da Cunha. Discipline of Nutrology/FMTM. Av. Getulio Guaritá s/n, 38025-440 Uberaba, MG, Brazil.

Telefax: 005534 318-5335.

e-mail:dfcnutro@mednet.com.br

Recebido para publicação em 19/2/2002.
} 
and food consumption, glucocorticoids may increase serum lipid levels ${ }^{311}$, by increasing hepatic triglyceride synthesis ${ }^{4}$ or due to iatrogenic ACTH deficiency ${ }^{3}$.

The new concepts about a possible protective role of triglyceride-rich lipoprotein on the immune system ${ }^{4} 12$ has stimulated the interest on the study of lipid profiles in different systemic inflammatory diseases. As data about metabolic changes in pemphigus foliaceus patients treated with glucocorticoids are scarce, we decided to compare the serum lipid levels of these patients with a healthy control group.

\section{MATERIAL AND METHODS}

The study was performed according to Declaration of Helsinki and all procedures were explained to participants before obtaining their informed consent. Fifteen (80\% female) patients with endemic pemphigus foliaceus (PF) hospitalized for long periods at Fogo Selvagem Hospital of Uberaba-MG, Brazil, were included in the study. The control group (CG) comprised fifteen $(73.3 \%$ female) healthy persons matched for demographic parameters. All volunteers were submitted to anthropometry and serum biochemical tests, besides $48 \mathrm{~h}$ food intake records.

Endemic pemphigus foliaceus diagnosis was based on clinical and skin histopathological data. All patients presented the generalized form of disease. None of the volunteers had history of diabetes mellitus, high blood pressure, diarrhea, malabsorption or renal insufficiency, and there were no signs or symptoms of acute infections. None of them was enrolled in regimens or taking drugs affecting appetite, except for pemphigus patients receiving immunosuppressive doses of prednisone $(0,33$ $\pm 0.22 \mathrm{mg} / \mathrm{kg}$ of body weight) for at least 12 months (median=22, range 12-112 months).

Anthropometry included weight, height, arm circumference and triceps skin fold determinations. Height was measured, without shoes, to the nearest $0.1 \mathrm{~cm}$ using a measuring tape. Weight was measured to the nearest $0.1 \mathrm{~kg}$, after voiding, without shoes and wearing light clothing, in fasted state on the morning. Triceps skin fold was measured on the non-dominant arm using a Holtain ${ }^{\circledR}$ skin fold caliper in a point halfway down the arm, between the scapula acromion and the ulna olecranon. Body mass index (BMI) was defined as weight in kilograms divided by height in square meters $\left(\mathrm{kg} / \mathrm{m}^{2}\right)$.
Dietary intake data for two consecutive weekdays was registered from all patients and controls. Basically, both groups consumed a diet based on typical rice and beans admixture, plus fruit, vegetables and meat, five to six times a day. To accurately estimate the consumed nutrients, kitchen utensils (plates, glasses, and spoons) and containers of known capacity were used. A registered dietician calculated daily food and energy intake using a PC program, and the food tables utilized were obtained from the U.S. Department of Agriculture, Handbook n 8, 1980, with some regional foods added 6 .

Daily energy expenditure was determined by HarrisBenedict formula ${ }^{14}$, and daily energy intake was calculated through actual energy intake x 100/ basal energy expenditure. All PF were able to stand up and walk around, and were engaged in light activities such as playing cards or domino. Controls had free-living daily light physical activities. All volunteers had fasting blood samples collected from a peripheral vein for serum lipids (triglyceride, total cholesterol, LDL, VLDL and HDL), in addition to serum creatinine and erythrocyte sedimentation rate (ESR).

Continuous variables with normal distribution were expressed as mean \pm SD and the "t" Student test was used in the comparison between groups. Mann-Whitney test was used for variables with non-normal distribution, which were expressed as median and range. The $c^{2}$ and Fishers' exact tests were used to compare frequency between groups. A value of $p<0.05$ was considered statistically significant.

\section{RESULTS}

PF and CG were matched, respectively, in relation to age (19.6 \pm 8.8 vs. $21.3 \pm 8.9$ years), weight (55.5 \pm 13.4 vs. $57.5 \pm 14.5 \mathrm{~kg})$, BMl $(24.9 \pm 6.4$ vs. $22.7 \pm 5.0 \mathrm{~kg} /$ $\left.\mathrm{m}^{2}\right)$, arm circumference $(27.8 \pm 4.6$ vs. $26.9 \pm 3.8 \mathrm{~cm})$, and triceps skin fold (22.0 \pm 9.2 vs. $21.1 \pm 9.7 \mathrm{~mm})$.

PF and CG consumed similar amounts of fat (107.0 \pm 38.8 vs. $97.0 \pm 22.4 \mathrm{~g})$, protein $(123.6 \pm 44.2$ vs. 103.2 $\pm 51.4 \mathrm{~g})$ and carbohydrate $(349.1 \pm 112.0$ vs. $301.8 \pm$
$149.4 \mathrm{~g})$, the same occurring with total $(2865.0 \pm 974.9$ vs. $2499.9 \pm 795.6 \mathrm{kcal})$ or BMR percentage $(231.1 \pm$ 77.7 vs. $177.8 \pm 58.1 \%$ ) of energy intake.

There were no differences between groups in relation to creatinine $(0.87 \pm 0.12$ vs. $0.77 \pm 0.20 \mathrm{mg} / \mathrm{dl})$, and cholesterol, HDL, and LDL serum levels; PF showed higher serum triglyceride and VLDL, as well as ESR levels (Table 1).

\section{DISCUSSION}

Increased ESR in PF suggests active inflammation in some of our cases ${ }^{911}{ }^{15}$, which also showed higher serum VLDL and triglyceride levels. Our data also suggest that these findings cannot be attributed to differences in demographic characteristics or daily dietary intake of fat or other macronutrients. These data are valuable because changes in serum lipids are not stereotyped in systemic inflammatory response, and may vary between patients with different inflammatory diseases, and be influenced by food intake pattern and/ or eventual effects of concurrent medication. 
Table 1 - Erythrocyte sedimentation rate (ESR) and serum lipids of normal controls and endemic pemphigus foliaceus patients on long-term glucocorticoid therapy at Fogo Selvagem Hospital of Uberaba-MG, Brazil.

\begin{tabular}{lcc}
\hline Parameters & Controls & Pemphigus \\
\hline ESR $(\mathrm{mm} / 1 \mathrm{st} \mathrm{hour})^{*}$ & $7(1-30)$ & $44(9-87)$ \\
Triglycerides $(\mathrm{mg} / \mathrm{dl})^{*}$ & $100(45-133)$ & $159(64-371)$ \\
Cholesterol $(\mathrm{mg} / \mathrm{dl})$ & $164(135-218)$ & $176(150-234)$ \\
HDL $(\mathrm{mg} / \mathrm{dl})$ & $40(24-60)$ & $35(21-77)$ \\
VLDL $(\mathrm{mg} / \mathrm{dl})^{*}$ & $20(9-114)$ & $32(13-74)$ \\
LDL $(\mathrm{mg} / \mathrm{dl})$ & $128(68-269)$ & $103(87-153)$ \\
\hline
\end{tabular}

Long-term glucocorticoid use is associated with increased serum lipids ${ }^{3} 413$. Other mechanisms of hypertriglyceridemia could also be involved in our PF cases. Non-specific acute or chronic immune activation often activate cytokines ${ }^{81113}$, which can enhance serum triglyceride levels, by increasing liver VLDL secretion and/ or by delayed peripheral clearance ${ }^{8}$. Moreover, ACTH has hypolipemic effect in healthy volunteers, and the hyperlipidemia observed in corticosteroid-treated patients may at least partly be secondary to iatrogenic ACTH deficiency ${ }^{3}$.

The use of glucocorticoids changed pemphigus from an almost invariably fatal disease into one with mortality below $10 \%{ }^{5}$. However, important side effects such as hypertension, diabetes mellitus, osteoporosis, infection, peptic ulcer, thrombosis and dyslipoproteinemia have been related. In order to minimize the incidence and severity of the undesirable effects, measures to allow lower corticoid dosages have been taken, including the use of immunosuppressive and anti-inflammatory agents as adjuvants ${ }^{5}$. Except in cases with very high triglyceride levels, one may be concerned about drug therapy for dyslipidemia in these patients, since TG-rich lipoproteins such as VLDL and chylomicrons are components of an innate, non-adaptive host immune response to infection ${ }^{12}$. However, a specific dietary orientation must be employed in all the cases of dyslipidemia.

The present study showed that pemphigus foliaceus patients had higher serum VLDL and triglyceride, in addition to increased ESR levels than controls, findings probably associated to the combined effects of inflammatory disease metabolic changes, and long-term corticoids use. Nevertheless, a better biochemical characterization of the acute phase response, and lipoprotein subfractions measurements should be done. It would be also advisable to perform these studies before and after long-term glucocorticoid use.

\section{ACKNOWLEDGEMENTS}

This work had financial support from Fundação de Ensino e Pesquisa de Uberaba (FUNEPU) and Fundação de Amparo à Pesquisa do Estado de Minas Gerais (FAPEMIG).

\section{REFERENCES}

1. Bakkaloglu A, Kirel B, Ozen S, Saatci U, Topaloglu R, Besbas N. Plasma lipids and lipoproteins in juvenile chronic arthritis. Clinical Rheumatology 15: 341-345, 1996.

2. Barraviera SRCS, Dillon NL, Curi PR, Pereira PCM, Almeida DB. Evaluation of nutritional status in patients with endemic pemphigus foliaceus. Revista do Instituto de Medicina Tropical de São Paulo 37: 51-58, 1995.

3. Berg AL, Nilsson-Ehle P. ACTH lowers serum lipids in steroidtreated hyperlipemic patients with kidney disease. Kidney International 50: 538-542, 1996.

4. Borba EF, Bonfa E. Long term beneficial effect of chloroquine diphosphate on lipoprotein profile in lupus patients with and without steroid therapy, Journal of Rheumatology 28: 780-785, 2001.

5. Bystryn JC, Steinman NM. The adjuvant therapy of pemphigus. An update. Archives of Dermatology 132: 203-212, 1996.

6. Cunha DF, Cunha SFC, Monteiro JP, Ferreira TPS, Santos JAM, Furtado RA, Marssaro RS, Muniz RA, Gomes RAS. Nutritional evaluation of pemphigus foliaceus patients on long term glucocorticoid therapy. Revista do Instituto de Medicina Tropical de São Paulo 42: 23-26, 2000.
7. Eversole LR. Immunopathology of oral mucosal ulcerative, desquamative, and bullous diseases. Selective review of the literature. Oral Surgery, Oral Medicine, Oral Pathology 77: 555-571, 1994.

8. Feingold KR, Hardardottir I, Grunfeld C. Beneficial effects of cytokine induced hyperlipidemia. Zeitschift fur Ernahrungswissenschaft 37 (supl 1): 66-74, 1998.

9. Franquini Junior J, Adad SJ, Murta AH, Morais CA, Teixeira VPA, Rodrigues Junior V. Tests of inflammatory activity in endemic pemphigus foliaceus. Revista da Sociedade Brasileira de Medicina Tropical 27: 25-29, 1994.

10. Friedman $\mathrm{H}$, Campbell I, Rocha-Alvarez R, Ferrari I, Coimbra CEA, Moraes JR, Flowers NM, Stastny P, Fernandez-Viña M, Olague-Alcala M, Diaz LA. Endemic pemphigus foliaceus (fogo selvagem) in native Americans from Brazil. Journal of the American Academy of Dermatology 32: 949-956, 1995.

11. Gabay C, Kushner I. Acute-phase proteins and other systemic responses to inflammation. New England Journal of Medicine 340: 448-454, 1999. 
12. Harris HW, Gosnell JE, Kumwenda ZL. The lipemia of sepsis: triglyceride-rich lipoproteins as agents of innate immunity, Journal of Endotoxin Research 6: 421-30, 2000.

13. Ilowite NT. Hyperlipidemia and the rheumatic diseases. Current Opinion in Rheumatology 8: 455-458, 1996.
14. Mizock BA, Troglia S. Nutritional support of the hospitalized patient. Disease-a-Month 43: 349-426, 1997.

15. Santos VM, Cunha SFC, Cunha DF. Velocidade de sedimentação das hemácias: utilidade e limitações. Revista da Associação Médica Brasileira 46: 232-236, 2000. 